\title{
TINGKAT KESELAMATAN PENGGUNA ZONA SELAMAT SEKOLAH (ZOSS) DI KOTA PADANG PANJANG
}

\author{
Helga Yermadona ${ }^{1}$, Elfania Bastian ${ }^{2}$ \\ Fakultas Teknik, Universitas Muhammadiyah Sumatera Barat ${ }^{1,2}$ \\ helga.umsb@gmail.com ${ }^{1}$,elfania_bastian@ymail.com² \\ DOI: http://dx.doi.org/10.31869/rtj.v2i2.1438
}

\begin{abstract}
Abstrak: Badan Pusat Statistik Kota Padang Panjang (2017) menyatakan jumlah kecelakaan lalu lintas yang terjadi di wilayah Padang Panjang tahun 2016 sebanyak 93 kejadian, angka tersebut mengalami kenaikan sebesar 126,83\% dibanding tahun sebelumnya. Data kecelakaan lalu lintas dari Korlantas Polri per Juli 2017 menunjukkan kelompok umur 15-19 tahun paling banyak jumlah korban kecelakaan. dimana kelompok umur tersebut termasuk kategori pelajar. Penelitian ini bertujuan untuk menganalisa tingkat keselamatan pengguna Zona Selamat Sekolah di Padang Panjang yaitu SDN 12 Silaiang Bawah, SMPN 3 Padang Panjang, dan SMAN 1 Padang Panjang berdasarkan Peraturan Direktur Jenderal Perhubungan Darat Nomor SK.3236/AJ.403/DJPD/2006 dan SK.3582/AJ.403/DJPD/2018. Metode yang digunakan adalah metode survei spot speed, perilaku anak sekolah saat menyeberang jalan, perilaku pengantar, dan volume kendaraan. Analisis menggunakan statistik uji Z dengan tingkat kesalahan 5\%, pada analisa kecepatan kendaraan menunjukkan hasil pejalan kaki sudah selamat, analisa perilaku anak sekolah saat menyeberang jalan perilaku anak sekolah belum selamat dan perilaku pengantar juga belum selamat, untuk analisis Level Of Service menggunakan PKJI 2014 didapatkan nilai $Q / C$ 0,332 - 0,637. Sehingga dengan kondisi tersebut, ZoSS di Padang Panjang masih membutuhkan pemantauan atau penjagaan lalu lintas dari petugas polisi setempat.
\end{abstract}

Kata kunci: Keselamatan, pelajar, Zona Selamat Sekolah, kecepatan dan Padang Panjang

Abstract: Padang Panjang statistics center (2017) stated that the number of traffic accidents occured in 2016 was 93, increased by 126,83\% compared to the previous year. Data on traffic accident from Indonesian National Traffic Police on July 2017 showed that ages 15-19, which is students age group, have the highest rate crash involvement. The present study aimed to analyze the safety level of school zone safety in Padang Panjang, i.e. SDN 12 Silaiang Bawah, SMPN 3 Padang Panjang, and SMAN 1 Padang Panjang based on Director General of Land Transportation Regulation number SK.3236/AJ.403/DJPD/2006 and SK.3582/AJ.403/DJPD/2018. The method used is the spot speed survey method, the students behavior when crossing the road, parents behavior when transporting children, and the volume of vehicle. The analysis used is $Z$ test statistics with $5 \%$ margin of error. The analysis of vehicle speed resulting that the pedestrians are secured, but the students and parents behavior are not secured, for analysis level of service used PKJI 2014 obtained Q/S value 0,3320,637. Thus, based on the condition, school zone safety in Padang Panjang needs to be monitored by local traffic police.

Keywords: safety, students, school zone safety, speed, and Padang Panjang

\section{PENDAHULUAN}

\section{Latar Belakang Masalah}

Kota Padang Panjang dengan jumlah penduduk pada tahun 2016, mengalami kenaikan jumlah kendaraan bermotor dalam lima tahun terakhir sebesar 39,98\%. Peningkatan jumlah kendaraan tersebut berdampak pada jumlah kecelakaan lalu lintas yang terjadi di wilayah Padang Panjang tahun 2016 sebanyak 93 kejadian, angka tersebut mengalami kenaikan sebesar $126,83 \%$ dibanding tahun sebelumnya (Badan Pusat Statistik Kota Padang Panjang, 2017). Berdasarkan data kecelakaan lalu lintas di Indonesia menunjukkan kelompok umur 15-19 tahun paling banyak jumlah korban kecelakaan. Tertinggi pada kelompok umur 15-19 tahun dengan jumlah korban luka ringan 3.496 jiwa, luka berat 400 jiwa 
dan meninggal dunia 535 jiwa (Kepolisian Republik Indonesia, 2017).

Kelompok umur 15-19 tahun termasuk kategori pelajar, sehingga diperlukan upaya untuk meminimalisir masalah kecelakaan dengan penerapan program pemasangan perlengkapan jalan (Zona Selamat Sekolah) pada ruas jalan yang lalu lintasnya ramai dan sering terjadi kecelakaan terutama di kawasan sekolah. Lokasi penempatan Zona Selamat Sekolah (ZoSS) untuk wilayah Kota Padang Panjang terdapat pada tiga lokasi sekolah, yaitu: SDN 12 Silaiang Bawah, SMPN 3 Padang Panjang, dan SMAN 1 Padang Panjang dengan tipe ZoSS 2UD-30.

Kondisi eksisting ZoSS di tiga sekolah wilayah kota Padang Panjang dapat dilihat pada Gambar 1 berikut ini:

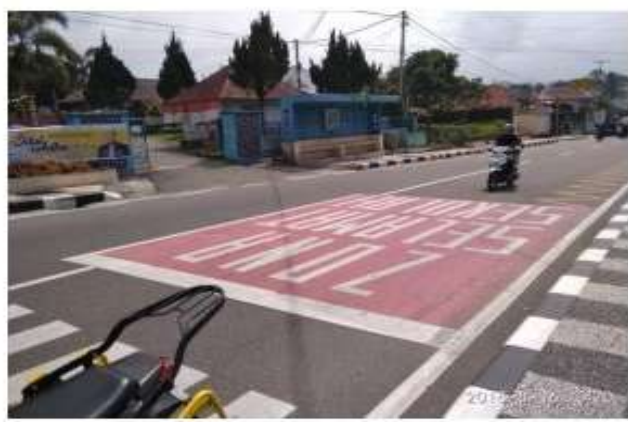

(a) SDN 12 Silaiang Bawah Jalan Sutan Syahrir

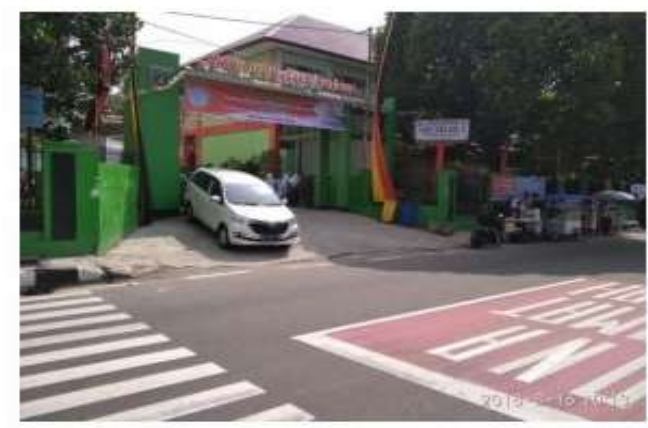

(b) SMPN 3 Padang Panjang Jalan Jenderal Ahmad Yani

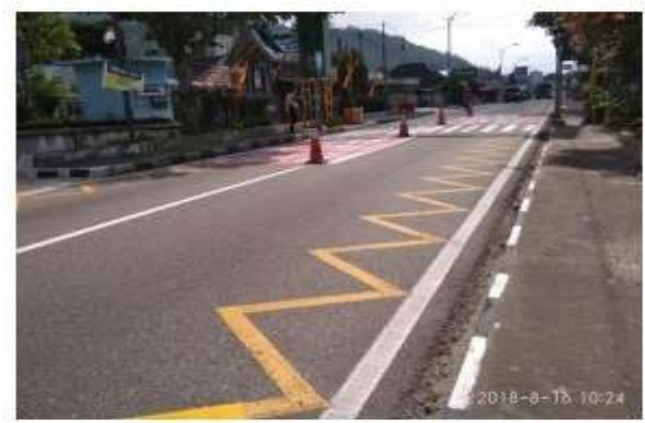

(c) SMAN 1 Padang Panjang Jalan K.H Ahmad Dahlan

Gambar 1. Kondisi eksisting ZoSS di kota Padang Panjang
Dari observasi singkat pada tiga lokasi ZoSS di atas, sekolah yang diteliti memiliki akses langsung ke jalan raya sehingga volume pelajar yang berjalan kaki dan menyeberang akan tinggi saat berangkat dan pulang sekolah. Semakin tinggi volume pejalan kaki dan penyeberang jalan tentu akan semakin tinggi pula resiko kecelakaan yang akan terjadi.

\section{Tujuan Penelitian}

Penelitian ini bertujuan untuk mengetahui tingkat keselamatan pengguna Zona Selamat Sekolah di tiga lokasi sekolah Padang Panjang berdasarkan Peraturan Direktur Jenderal Perhubungan Darat Nomor SK.3236/AJ.403/DJPD/2006 dan SK.3582/AJ.403/DJPD/2018. Tingkat keselamatan dapat dianalisa berdasarkan kecepatan sesaat (spot speed), perilaku anak sekolah saat menyeberang jalan, perilaku pengantar anak sekolah, dan tingkat pelayanan jalan (level of service) berdasarkan PKJI 2014.

\section{TINJAUAN PUSTAKA}

Defenisi ZoSS adalah pengendalian kegiatan lalu lintas melalui pengaturan kecepatan dengan penempatan marka dan rambu pada ruas jalan di lingkungan sekolah yang bertujuan untuk mencegah terjadi kecelakaan sebagai upaya menjamin keselamatan di sekolah (Direktur Jenderal Perhubungan Darat, 2014). Direktur Jenderal Perhubungan Darat pada tahun 2018 menyempurnakan

SK.3236/AJ.403/DRJD/2006 dengan peraturan yang baru, yaitu SK.3582/AJ.403/DJPD/2018 tentang pedoman teknis pemberian prioritas keselamatan dan kenyamanan pejalan kaki pada kawasan sekolah melalui penyediaan ZoSS (Direktur Jenderal Perhubungan Darat, 2018).

Beberapa penelitian yang pernah dilakukan berkaitan dengan Zona Selamat Sekolah (ZoSS), diantaranya membahas perbedaan SK yang baru (2014) dengan SK yang lama (2006) adalah telah disusunnya materi sosialisasi tentang tata cara berlalu lintas yang berkeselamatan di ZoSS, petugas pemandu penyeberang, dan variasi ZoSS (tunggal dan jamak), sehingga penerapan ZoSS akan lebih efektif dan desain marka 
ZoSS yang baru lebih efisien dibandingkan dengan desain marka ZoSS yang lama. ZoSS dapat diklasifikasikan berdasarkan letak sekolah, yaitu ZoSS tunggal dan ZoSS jamak. ZoSS tunggal merupakan ZoSS yang ditetapkan untuk 1 (satu) sekolah di suatu lokasi. ZoSS jamak merupakan ZoSS yang ditetapkan untuk 2 (dua) atau lebih sekolah yang lokasinya berdekatan (Arisandi, 2016).

Menurut penelitian lainnya, hasil kecepatan kendaraan yang melewati wilayah ZoSS di Jalan Lintas Timur Provinsi Riau tidak sesuai dengan kecepatan izin yaitu $34 \mathrm{~km} / \mathrm{jam}$ sedangkan kecepatan rata-rata pada wilayah yang tidak memilki fasilitas ZoSS adalah 36 $\mathrm{km} / \mathrm{jam}$. Hal ini menunjukkan bahwa kendaraan yang melewati ZoSS ini tidak mengikuti peraturan batas maksimum wilayah ZoSS dan dapat berpotensi membahayakan siswa-siswa Sekolah Dasar pengguna jalan (Soehardi, Putri, and Saleh, 2017).

Hasil penelitian ZoSS di Kota Padang belum berjalan sesuai rencana. Hal tersebut dapat terlihat dari perilaku penyeberang jalan dan pengantar serta kecepatan kendaraan bermotor pada lokasi penelitian yang menunjukkan bahwa siswa sekolah belum selamat meskipun ada ZoSS, kecuali ada bantuan petugas Polisi (Kurniati, Gunawan, and Zulputra, 2010).

Penelitian ZoSS di Kota Malang, dengan kesimpulan penerapan ZoSS kurang efektif, terjadi penurunan perilaku penyeberang jalan dan pengendara kendaraan (Dalono, Sulistio, and P Nurhadi 2012). Penelian lain tentang Persepsi Pengguna Fasilitas ZoSS (Zona Selamat Sekolah) menyatakan penyeberang dan pengendara kendaraan kurang pemahamannya terhadap ZoSS. Metode menyeberang jalan dengan prosedur 4-T belum dikenal dengan baik oleh responden (Kusmaryono, Rusgiyarto, and Widjajanti, 2010).

Jenis survei yang dilakukan di ZoSS (Direktur Jenderal Perhubungan Darat 2006) yaitu:

1. Survei perilaku anak sekolah saat menyeberang jalan

2. Survei kecepatan sesaat (spot speed)

3. Survei volume kendaraan

4. Survei perilaku pengantar

Semua survei minimal dilaksanakan 30 menit pada pagi sebelum jam sekolah dan siang setelah pulang sekolah. Untuk kriteria yang akan dinilai terhadap karakter siswa dalam menyeberang jalan yaitu:

1. Prosedur baku cara menyeberang/4T (Tunggu sejenak, Tengok kanan, Tengok kiri, Tengok kanan lagi)

2. Cara menyeberang (berjalan atau berlari)

3. Fasilitas yang digunakan (dengan zebra cross atau jembatan penyeberangan orang /JPO atau tanpa fasilitas)

4. Status penyeberang (mandiri atau tidak mandiri.

Untuk kriteria yang akan dinilai pengukuran perilaku pengantar yaitu:

1. Arah kedatangan kendaraan (kiri dan kanan)

2. Lokasi berhenti (pada tempatnya atau sembarangan)

3. Naik/turun anak dari kendaraan (sisi kiri trotoar atau sisi kanan di badan jalan)

Rumus yang digunakan untuk menganalisis kecepatan kendaraan menurut Direktur Jenderal Perhubungan Darat (2006) adalah uji $\mathrm{Z}$ dengan tingkat kesalahan 5\%:

$\mathrm{Z}_{\text {hit }}=\frac{\overline{\mathrm{X}}-\text { kec rerata ZoSS }}{\frac{\mathrm{Sd}}{\sqrt{\mathrm{n}}}}$

$S d=\sqrt{\frac{\sum\left(X_{i}-\bar{X}\right)^{2}}{n-1}}$

$\overline{\mathrm{X}}=\frac{\sum \mathrm{X}_{\mathrm{i}}}{\mathrm{n}}$

Rumus yang digunakan untuk menganalisis perilaku anak sekolah saat menyeberang jalan dan perilaku pengantar menurut Direktur Jenderal Perhubungan Darat (2006) adalah uji $\mathrm{Z}$ dengan tingkat kesalahan 5\%:

$$
\mathrm{Z}_{\text {hit }}=\frac{\overline{\mathrm{P}}-0,5}{\sqrt{\frac{\overline{\mathrm{P}}(1-\overline{\mathrm{P}})}{n}}}
$$




$$
\overline{\mathrm{P}}=\frac{\sum \text { Kelompok }}{\mathrm{n}}
$$

Kesimpulan hasil uji $\mathrm{Z}$ didapatkan dengan membandingkan nilai $\mathrm{Z}_{\text {hit }}$ dan $\mathrm{Z}_{\text {tabel }}$, nilai $\mathrm{Z}_{\text {tabel }}$ untuk tingkat kesalahan 5\% $=1,645$

Keterangan:

$$
\begin{array}{ll}
\overline{\mathrm{X}} & \text { : kecepatan rata-rata kendaraan } \\
\mathrm{X}_{\mathrm{i}} & \text { : kecepatan sesaat (spot speed) } \\
\mathrm{n} & \text { : jumlah sampel } \\
\mathrm{Sd} & \text { : standar deviasi } \\
\overline{\mathrm{P}} & \text { : proporsi sampel }
\end{array}
$$

Kinerja jalan diwakili oleh tingkat pelayanan (level of service, LOS) yaitu suatu ukuran kualitatif yang mencerminkan persepsi

\begin{tabular}{|c|c|c|}
\hline $\begin{array}{c}\text { LO } \\
\text { S }\end{array}$ & $\begin{array}{c}\text { Karakteristik Lalu } \\
\text { Lintas }\end{array}$ & $Q / C$ \\
\hline A & $\begin{array}{l}\text { Kondisi arus lalu lintas } \\
\text { bebas dengan kecepatan } \\
\text { tinggi dan volume lalu } \\
\text { lintas rendah }\end{array}$ & $\begin{array}{c}0,00- \\
0,20\end{array}$ \\
\hline B & $\begin{array}{l}\text { Arus stabil, tetapi } \\
\text { kecepatan gerak } \\
\text { kendaraan dikendalikan }\end{array}$ & $\begin{array}{c}0,20- \\
0,44\end{array}$ \\
\hline $\mathrm{C}$ & $\begin{array}{l}\text { Arus stabil, tetapi } \\
\text { kecepatan operasi mulai } \\
\text { dibatasi oleh kondisi lalu } \\
\text { lintas }\end{array}$ & $\begin{array}{c}0,45- \\
0,74\end{array}$ \\
\hline $\mathrm{D}$ & $\begin{array}{ll}\text { Arus mendekati } & \text { stabil, } \\
\text { kecepatan masih } & \text { dapat } \\
\text { dikendalikan, V/C masih } \\
\text { dapat ditolerir }\end{array}$ & $\begin{array}{c}0,75- \\
0,84\end{array}$ \\
\hline $\mathrm{E}$ & $\begin{array}{lr}\text { Arus tidak } & \text { stabil, } \\
\text { kecepatan } & \text { terkadang } \\
\text { terhenti, } & \text { permintaan } \\
\text { sudah } & \text { mendekati } \\
\text { kapasitas } & \end{array}$ & $\begin{array}{c}0,85- \\
1,00\end{array}$ \\
\hline $\mathrm{F}$ & $\begin{array}{l}\text { Arus dipaksakan, } \\
\text { kecepatan rendah, volume } \\
\text { di atas kapasitas, antrian } \\
\text { panjang (macet) }\end{array}$ & $>1,00$ \\
\hline
\end{tabular}
pengemudi tentang kualitas berkendaraan (Kementrian Pekerjaan Umum, 2014). Tingkat pelayanan jalan dapat dilihat pada Tabel 1 berikut ini:

Tabel 1. Tingkat pelayanan jalan

Sumber: Departemen Pekerjaan Umum (2014)

Kapasitas jalan perkotaan dapat dihitung menggunakan rumus berikut:

$$
C=C_{0} x F C_{L I} x F C_{P A} x F C_{H S} x F C_{U K}
$$

Keterangan:

C : kapasitas (skr/jam)

$C_{0} \quad$ : kapasitas dasar (skr/jam)

$F C_{L J}$ : faktor penyesuaian kapasitas terkait lebar lajur atau jalur lalu lintas

$F C_{P A}$ : faktor penyesuaian kapasitas terkait pemisahan arah

$F C_{H S}$ : faktor penyesuaian kapasitas terkait KHS pada jalan berbahu/berkereb

$F C_{U K}$ : faktor penyesuaian kapasitas terkait ukuran kota

Menurut Departemen Pekerjaan Umum (2014), derajat kejenuhan adalah rasio antara arus lalu lintas terhadap kapasitas jalan dapat dicari dengan rumus:

$D j=\frac{Q}{C}$

Keterangan:

$\mathrm{Dj}=$ Derajat kejenuhan

$\mathrm{Q}=$ Arus lalu lintas (skr/jam)

$\mathrm{C}=$ Kapasitas (skr/jam)

\section{METODE PENELITIAN}

Metode penelitian dilakukan dengan beberapa tahap berikut ini:

1. Studi pendahuluan dengan cara menentukan lokasi penelitian yaitu sekolah dengan fasilitas ZoSS di kota Padang Panjang (SDN 12 Silaiang Bawah, SMPN 3 Padang Panjang, dan SMAN 1 Padang Panjang dengan tipe ZoSS 2UD-30).

2. Penentuan periode survei dilakukan pada hari sekolah yang dilakukan minimal 30 menit pada waktu pagi (sebelum sekolah masuk) dan siang (saat pulang sekolah).

3. Pengumpulan data jumlah siswa sekolah untuk menentukan jumlah sampel minimal penelitian $10 \%$ dari jumlah siswa sekolah. Berdasarkan website Dinas Pendidikan jumlah siswa SDN 12 Silaiang Bawah sebanyak 201 siswa (sampel minimal 20 orang), SMPN 3 Padang Panjang sebanyak 549 siswa (sampel minimal 55 orang), dan SMAN 1 Padang 
Panjang sebanyak 836 siswa (sampel minimal 84 orang).

4. Alat survei yang digunakan yaitu stop watch, formulir survei spot speed, formulir survei perilaku penyeberang jalan, perilaku pengantar, formulir survei volume lalu lintas, alat tulis, dan meteran.

5. Analisis data hasil survei:

a. Analisis kecepatan, perilaku anak sekolah menyeberang jalan dan perilaku pengantar menggunakan statistik uji Z.

b. Analisis volume kendaraan, tingkat pelayanan jalan (Level of Service) menggunakan PKJI 2014.

6. Tingkat keselamatan pengguna ZoSS dapat disimpulkan berdasarkan hipotesis dari perbandingan nilai $\mathrm{Z}_{\text {hit }}$ dan $\mathrm{Z}_{\text {tabel }}$ :

a. Analisis kecepatan, jika $\mathrm{Z}_{\text {hit }}>$ $\mathrm{Z}_{\text {tabel }}$ maka pejalan kaki "belum selamat" dengan tingkat kesalahan $5 \%$. Jika $\mathrm{Z}_{\text {hit }}<\mathrm{Z}_{\text {tabel }}$ maka pejalan kaki "selamat" dengan tingkat kesalahan 5\%.

b. Analisis perilaku penyeberang jalan dan perilaku pengantar, jika $\mathrm{Z}_{\text {hit }}>\mathrm{Z}_{\text {tabel }}$ maka perilaku penyeberang atau pengantar "selamat" dengan tingkat kesalahan $5 \%$. Jika $\mathrm{Z}_{\text {hit }}<\mathrm{Z}_{\text {tabel }}$ maka perilaku penyeberang atau pengantar "belum selamat" dengan tingkat kesalahan 5\%

\section{HASIL DAN PEMBAHASAN \\ Kondisi Eksisting}

Kondisi eksisting lokasi penelitian dari hasil survei dan pengukuran langsung di lapangan dapat dilihat pada Tabel 2 berikut:

Tabel 2 Data kondisi eksisting

\begin{tabular}{|l|c|c|c|}
\hline Lokasi & $\begin{array}{c}\text { SDN 12 } \\
\text { Silaiang } \\
\text { Bawah }\end{array}$ & $\begin{array}{c}\text { SMPN 3 } \\
\text { Padang } \\
\text { Panjang }\end{array}$ & $\begin{array}{c}\text { SMAN 1 } \\
\text { Padang } \\
\text { Panjang }\end{array}$ \\
\hline $\begin{array}{l}\text { Lebar } \\
\text { jalan }\end{array}$ & $7 \mathrm{~m}$ & $9,25 \mathrm{~m}$ & $8,20 \mathrm{~m}$ \\
\hline $\begin{array}{l}\text { Panjang } \\
\text { ZoSS }\end{array}$ & $170 \mathrm{~m}$ & $141,7 \mathrm{~m}$ & $185 \mathrm{~m}$ \\
\hline $\begin{array}{l}\text { Tipe } \\
\text { ZoSS }\end{array}$ & 2UD-30 & 2UD-30 & 2UD-30 \\
\hline
\end{tabular}

Berdasarkan Tabel 2 di atas, dapat disimpulkan bahwa tipe ZoSS di Kota Padang Panjang adalah 2UD-30 yang artinya terletak pada jalan 2 lajur tidak terbagi dengan batas kecepatan pada ZoSS adalah $30 \mathrm{~km} / \mathrm{jam}$.

Analisa Kecepatan Kendaraan

Hasil analisa survei kecepatan kendaraan (spot speed) pada lokasi penelitian dapat dilihat pada Tabel 3 berikut:

Tabel 3 Data analisa kecepatan kendaraan

\begin{tabular}{|c|c|c|c|c|}
\hline $\begin{array}{c}\text { Wakt } \\
\text { u }\end{array}$ & Data & $\begin{array}{c}\text { SDN } \\
12 \\
\text { Silaian } \\
\text { g } \\
\text { Bawah }\end{array}$ & $\begin{array}{c}\text { SMPN } \\
\mathbf{3} \\
\text { Padan } \\
\text { g } \\
\text { Panjan } \\
\text { g } \\
\end{array}$ & $\begin{array}{c}\text { SMAN } \\
1 \\
\text { Padan } \\
\text { g } \\
\text { Panjan } \\
\text { g } \\
\end{array}$ \\
\hline \multirow[t]{5}{*}{ Pagi } & $\begin{array}{l}\overline{\bar{X}} \\
(\mathrm{~km} / \mathrm{ja} \\
\mathrm{m})\end{array}$ & 15,40 & 17,82 & 16,78 \\
\hline & Std & 3,729 & 4,506 & 3,597 \\
\hline & $\mathrm{Z}_{\text {hit }}$ & $\begin{array}{c}- \\
15,167\end{array}$ & $-10,470$ & $-14,230$ \\
\hline & $\mathrm{Z}_{\text {tabel }}$ & 1,645 & 1,645 & 1,645 \\
\hline & Hasil & selamat & selamat & selamat \\
\hline \multirow[t]{5}{*}{ Siang } & $\begin{array}{l}\overline{\bar{X}} \\
(\mathrm{~km} / \mathrm{ja} \\
\mathrm{m})\end{array}$ & 19,28 & 17,45 & 16,82 \\
\hline & Std & 1,722 & 3,894 & 4,231 \\
\hline & $\mathrm{Z}_{\text {hit }}$ & $\begin{array}{c}- \\
24,125\end{array}$ & $-12,483$ & $-12,061$ \\
\hline & $\mathrm{Z}_{\text {tabel }}$ & 1,645 & 1,645 & 1,645 \\
\hline & Hasil & selamat & selamat & $\begin{array}{c}\text { Selama } \\
t\end{array}$ \\
\hline
\end{tabular}

Berdasarkan Tabel 3 di atas dapat disimpulkan bahwa pada analisa kecepatan kendaraan di tiga lokasi penelitian didapatkan nilai $\mathrm{Z}_{\text {hit }}<\mathrm{Z}_{\text {tabel }}$ maka pejalan kaki "selamat" dengan tingkat kesalahan 5\%.

Analisa Perilaku Anak Sekolah Saat Menyeberang Jalan

Hasil analisa perilaku anak sekolah saat menyeberang jalan pada lokasi penelitian dapat dilihat pada Tabel 4 berikut: 
Vol. 2 No.2 Juni 2019

http://jurnal.umsb.ac.id/index.php/RANGTEKNIKJOURNAL

Tabel 4 Data analisa perilaku anak sekolah saat menyeberang jalan

\begin{tabular}{|c|c|c|c|c|}
\hline $\begin{array}{c}\text { Wakt } \\
\text { u }\end{array}$ & Data & $\begin{array}{c}\text { SDN } \\
12 \\
\text { Silaia } \\
\text { ng } \\
\text { Bawa } \\
\text { h }\end{array}$ & $\begin{array}{c}\text { SMPN } \\
3 \\
\text { Padan } \\
\text { g } \\
\text { Panja } \\
\text { ng }\end{array}$ & $\begin{array}{c}\text { SMAN } \\
1 \\
\text { Padan } \\
\text { g } \\
\text { Panja } \\
\text { ng }\end{array}$ \\
\hline \multirow{6}{*}{ Pagi } & $\mathrm{n}$ & 24 & 61 & 95 \\
\hline & $\begin{array}{l}\Sigma \text { kelomp } \\
\text { ok }\end{array}$ & 1 & 26 & 64 \\
\hline & $\overline{\mathrm{P}}$ & 0,042 & 0,426 & 0,674 \\
\hline & $\mathrm{Z}_{\text {hit }}$ & $\begin{array}{c}- \\
11,237\end{array}$ & $-1,165$ & 3,611 \\
\hline & $\mathrm{Z}_{\text {tabel }}$ & 1,645 & 1,645 & 1,645 \\
\hline & Hasil & $\begin{array}{c}\text { Belum } \\
\text { selama } \\
\mathrm{t}\end{array}$ & $\begin{array}{c}\text { Belum } \\
\text { selama } \\
\mathrm{t}\end{array}$ & $\begin{array}{c}\text { Selama } \\
\mathrm{t}\end{array}$ \\
\hline \multirow{6}{*}{ Siang } & $\mathrm{n}$ & 22 & 62 & 95 \\
\hline & $\begin{array}{l}\Sigma \text { kelomp } \\
\text { ok }\end{array}$ & 3 & 11 & 35 \\
\hline & $\overline{\mathrm{P}}$ & 0,136 & 0,177 & 0,368 \\
\hline & $\mathrm{Z}_{\text {hit }}$ & $-4,970$ & $-6,649$ & -2.659 \\
\hline & $\mathrm{Z}_{\text {tabel }}$ & 1,645 & 1,645 & 1,645 \\
\hline & Hasil & $\begin{array}{l}\text { Belum } \\
\text { selama } \\
\mathrm{t}\end{array}$ & $\begin{array}{l}\text { Belum } \\
\text { selama } \\
\mathrm{t}\end{array}$ & $\begin{array}{l}\text { Belum } \\
\text { selama } \\
t\end{array}$ \\
\hline
\end{tabular}

Berdasarkan Tabel 4 di atas dapat disimpulkan bahwa pada analisa perilaku anak sekolah saat menyeberang jalan hanya di SMAN 1 Padang Panjang nilai $\mathrm{Z}_{\text {hit }}>\mathrm{Z}_{\text {tabel }}$ pada pagi hari perilaku anak sekolah saat menyeberang jalan "selamat" dengan tingkat kesalahan 5\%. Sayangnya rata-rata hasil analisis menunjukkan nilai $\mathrm{Z}_{\text {hit }}<\mathrm{Z}_{\text {tabel }}$ maka perilaku anak sekolah saat menyeberang jalan "belum selamat" dengan tingkat kesalahan 5\%. Sehingga untuk perilaku anak sekolah saat menyeberang jalan masih membutuhkan bantuan pemantauan atau penjagaan lalu lintas dari petugas polisi setempat agar selamat.

\section{Analisa Perilaku Pengantar}

Hasil analisa perilaku pengantar pada lokasi penelitian dapat dilihat pada Tabel 5 berikut:
Tabel 5 Data analisa perilaku pengantar

\begin{tabular}{|c|c|c|c|c|}
\hline $\begin{array}{c}\text { Wakt } \\
\text { u }\end{array}$ & Data & $\begin{array}{c}\text { SDN } \\
12 \\
\text { Silaia } \\
\text { ng } \\
\text { Bawa } \\
\text { h }\end{array}$ & $\begin{array}{c}\text { SMPN } \\
3 \\
\text { Padan } \\
\text { g } \\
\text { Panja } \\
\text { ng }\end{array}$ & $\begin{array}{c}\text { SMAN } \\
1 \\
\text { Padan } \\
\text { g } \\
\text { Panja } \\
\text { ng }\end{array}$ \\
\hline \multirow{6}{*}{ Pagi } & $\mathrm{n}$ & 23 & 61 & 95 \\
\hline & $\begin{array}{l}\Sigma \text { kelomp } \\
\text { ok }\end{array}$ & 1 & 1 & 2 \\
\hline & $\overline{\mathrm{P}}$ & 0,043 & 0,016 & 0,021 \\
\hline & $\mathrm{Z}_{\text {hit }}$ & $\begin{array}{c}- \\
10,736\end{array}$ & $\begin{array}{c}- \\
29,745\end{array}$ & $\begin{array}{c}- \\
32,518\end{array}$ \\
\hline & $\mathrm{Z}_{\text {tabel }}$ & 1,645 & 1,645 & 1,645 \\
\hline & Hasil & $\begin{array}{l}\text { Belum } \\
\text { selama } \\
\mathrm{t}\end{array}$ & $\begin{array}{c}\text { Belum } \\
\text { selama } \\
\mathrm{t}\end{array}$ & $\begin{array}{c}\text { Belum } \\
\text { selama } \\
\mathrm{t}\end{array}$ \\
\hline \multirow{6}{*}{ Siang } & $\mathrm{n}$ & 22 & 62 & 95 \\
\hline & $\begin{array}{l}\text { Skelomp } \\
\text { ok }\end{array}$ & 1 & 1 & 1 \\
\hline & $\overline{\mathrm{P}}$ & 0,045 & 0,016 & 0,011 \\
\hline & $\mathrm{Z}_{\text {hit }}$ & $\begin{array}{c}- \\
10,235\end{array}$ & $\begin{array}{c}- \\
30,245\end{array}$ & $\begin{array}{c}- \\
46,747\end{array}$ \\
\hline & $\mathrm{Z}_{\mathrm{t} \text { tabel }}$ & 1,645 & 1,645 & 1,645 \\
\hline & Hasil & $\begin{array}{l}\text { Belum } \\
\text { selama } \\
\mathrm{t}\end{array}$ & $\begin{array}{c}\text { Belum } \\
\text { selama } \\
\mathrm{t}\end{array}$ & $\begin{array}{c}\text { Belum } \\
\text { selama } \\
\mathrm{t}\end{array}$ \\
\hline
\end{tabular}

Berdasarkan Tabel 5 di atas dapat disimpulkan bahwa pada analisa perilaku pengantar pada lokasi penelitian, rata-rata hasil analisis menunjukkan nilai $\mathrm{Z}_{\text {hit }}<\mathrm{Z}_{\text {tabel }}$ maka perilaku anak sekolah saat menyeberang jalan "belum selamat" dengan tingkat kesalahan 5\%. Sehingga untuk perilaku pengantar masih membutuhkan bantuan pemantauan atau penjagaan lalu lintas dari petugas polisi setempat agar selamat.

\section{Analisa Lalu Lintas dan Tingkat Pelayanan Jalan (Level of Service/LOS)}

Hasil analisa lalu lintas dan tingkat pelayanan jalan pada lokasi penelitian dapat dilihat pada Tabel 6 berikut:

Tabel 6 Data lalu lintas dan tingkat pelayanan jalan (Level of Service/ LOS)

\begin{tabular}{|l|c|c|c|}
\hline \multicolumn{1}{|c|}{ Data } & $\begin{array}{c}\text { SDN 12 } \\
\text { Silaiang } \\
\text { Bawah }\end{array}$ & $\begin{array}{c}\text { SMPN 3 } \\
\text { Padang } \\
\text { Panjang }\end{array}$ & $\begin{array}{c}\text { SMAN 1 } \\
\text { Padang } \\
\text { Panjang }\end{array}$ \\
\hline $\begin{array}{l}\text { Q } \\
\text { (skr/jam) }\end{array}$ & 1344,70 & 874,80 & 1082,60 \\
\hline C & 2109,924 & 2637,405 & 2405,313 \\
\hline
\end{tabular}


Vol. 2 No.2 Juni 2019

http://jurnal.umsb.ac.id/index.php/RANGTEKNIKJOURNAL

\begin{tabular}{|l|c|c|c|}
\hline (skr/jam) & & & \\
\hline $\mathrm{Q} / \mathrm{C}$ & 0,637 & 0,332 & 0,450 \\
\hline LOS & $\mathrm{C}$ & $\mathrm{B}$ & $\mathrm{C}$ \\
\hline
\end{tabular}

Berdasarkan Tabel 6 di atas dapat disimpulkan bahwa nilai $\mathrm{Q} / \mathrm{C}$ pada lokasi penelitian berkisar antara $0,332-0,637$. Level of Service (LOS) pada level B di SMPN 3 Padang Panjang artinya arus stabil, tetapi kecepatan gerak kendaraan dikendalikan. Level of Service (LOS) pada level C di SDN 12 Silaiang Bawah dan SMAN 1 Padang Panjang artinya arus stabil, tetapi kecepatan operasi mulai dibatasi oleh kondisi lalu lintas.

\section{PENUTUP}

Kesimpulan dan saran yang didapat dari hasil dan pembahasan penelitian adalah sebagai berikut:

1. Kota Padang Panjang mempunyai fasilitas Zona Selamat Sekolah tipe 2UD-30 dengan batas kecepatan 30 $\mathrm{km} / \mathrm{jam}$ pada tiga sekolah yaitu SDN 12 Silaiang Bawah, SMPN3 Padang Panjang dan SMAN 1 Padang Panjang.

2. Tingkat keselamatan pada analisa kecepatan kendaraan didapatkan nilai $\mathrm{Z}_{\text {hit }}<\mathrm{Z}_{\text {tabel }}$ maka pejalan kaki "selamat" dengan tingkat kesalahan $5 \%$.

3. Tingkat keselamatan pada analisa perilaku anak sekolah saat menyeberang jalan pada lokasi penelitian hanya di SMAN 1 Padang Panjang yang menunjukkan hasil "selamat" pada survey pagi hari. Sedangkan hasil lainnya nilai $\mathrm{Z}_{\text {hit }}<$ $\mathrm{Z}_{\text {tabel }}$ maka perilaku anak sekolah saat menyeberang jalan "belum selamat" dengan tingkat kesalahan 5\%.

4. Tingkat keselamatan analisa perilaku pengantar pada lokasi penelitian nilai $\mathrm{Z}_{\text {hit }}<\mathrm{Z}_{\text {tabel }}$ maka perilaku anak sekolah saat menyeberang jalan "belum selamat" dengan tingkat kesalahan 5\%.

5. Analisa tingkat pelayanan jalan (Level of Service/LOS) pada lokasi penelitian SDN 12 Silaiang Bawah dan SMAN 1 Padang Panjang pada level $\mathrm{C}$ dan SMPN 3 Padang Panjang pada level B.
6. Untuk mencapai tingkat keselamatan "selamat" pada perilaku anak sekolah penyeberang jalan dan perilaku pengantar masih membutuhkan bantuan pemantauan atau penjagaan lalu lintas dari petugas polisi setempat.

\section{UCAPAN TERIMAKASIH}

Terima kasih kepada Kemenristekdikti, Direktorat Riset dan Pengabdian Masyarakat yang telah memberikan hibah pembiayaan penelitian ini. Mahasiswa dan alumni Teknik Sipil FT-UMSB yang telah membantu survei pengambilan data di lapangan.

\section{DAFTAR PUSTAKA}

Arisandi, Yogi. 2016. "Rencana Penerapan Zona Selamat Sekolah (ZoSS) Di Kota Kediri, Jawa Timur." Penelitian Transportasi Darat 18(4):285-300.

Badan Pusat Statistik Kota Padang Panjang. 2017. Kota Padang Panjang Dalam Angka. Padang Panjang.

Dalono, Harnen Sulistio, and Imam P Nurhadi. 2012. "Kajian Program Aksi Keselamatan Transportasi Jalan: Kasus Zona Selamat Sekolah ( Zoss ) Dan Potensi Penerapan Lajur Sepeda Motor Di Kota." Rekayasa Sipil 6(3):199-213.

Direktur Jenderal Perhubungan Darat. 2006. Peraturan Direktur Jenderal Perhubungan Darat Nomor: SK.3236/AJ403/DRJD/2006 Tentang Uji Coba Penerapan Zona Selamat Sekolah Di 11 (Sebelas) Kota Di Pulau Jawa. Jakarta.

Direktur Jenderal Perhubungan Darat. 2014. Peraturan Direktur Jenderal Perhubungan Darat Nomor: SK.1304/AJ.403/DJPD/2014 Tentang Zona Selamat Sekolah (ZoSS). Jakarta.

Direktur Jenderal Perhubungan Darat. 2018. Peraturan Direktur Jenderal Perhubungan Darat Nomor: SK.3582/AJ.403/DJPD/2018 Tentang Pedoman Teknis Pemberian Prioritas Keselamatan Dan Kenyamanan Pejalan Kaki Pada Kawasan Sekolah Melalui Penyediaan Zona Selamat Sekolah. Jakarta.

Kementrian Pekerjaan Umum. 2014. Pedoman 
Kapasitas Jalan Perkotaan. Jakarta.

Kepolisian Republik Indonesia. 2017. Jumlah

Korban Kecelakaan Lalu Lintas, Mei-Juli

2017.

Kurniati, Titi, Hendra Gunawan, and Dony Zulputra. 2010. "Evaluasi Penerapan Zona Selamat Sekolah Di Kota Padang." Rekayasa Sipil 6(2):55-64.

Kusmaryono, Ismono, Ferry Rusgiyarto, and Endang Widjajanti. 2010. "Persepsi Pengguna Fasilitas Zona Selamat Sekolah." Transportasi 10(3):205-14.

Soehardi, Fitridawati, Dwi Lusi Putri, and Alfian Saleh. 2017. "Tinjauan Kecepatan Kendaraan Pada Wilayah ZoSS Di Jalan Lintas Timur Provinsi Riau." Teknik Sipil Siklus 3(2):77-85. 